\title{
Moderating Effect of Audit Quality on the Relationship Between Board Characteristics and Audit Report Lag of Listed Non-Financial Companies in Nigeria
}

\author{
Ahmed Ishaku $^{1} \quad$ ACA, Habib Abdulkarim² $\quad$ CNA \& Halima S. Mohammed ${ }^{2}$ \\ 1. Department of Accounting Gombe State University, Nigeria \\ 2.Department of Accounting Federal University Kashere, Nigeria
}

\begin{abstract}
This study examined the moderating effect of audit quality on the relationship between board characteristics and audit report lag of listed non-financial companies in Nigeria. The ex-post facto research design was adopted, secondary data was extracted from annual reports and accounts of thirty-one listed non-financial companies for six years (2013-2018). Data were analyzed using system dynamic panel-data estimation technique; the findings revealed a negative and significant effect of board size on audit report lag, board independence has a positive but non-significant effect on audit report lag, however, board meeting has a positive and significant effect on audit report lag. Besides, audit quality has a negative and significant moderating effect on the relationship between board characteristics and audit report lag of listed non-financial companies in Nigeria. The study concludes that audit quality moderates the relationship between board characteristics and audit report lag of listed non-financial companies in Nigeria and recommended strict adherence to regulatory guidelines to avoid regulatory fines.
\end{abstract}

Keywords: Audit Quality, Board Characteristics and Audit Report Lag

DOI: $10.7176 / \mathrm{RJFA} / 12-8-06$

Publication date: April $30^{\text {th }} 2021$

\section{INTRODUCTION}

The need for timely release of financial statements cannot be underestimated in consideration of the consequences and regulatory fines for delay in the release of financial reports and accounts. However, in Nigeria, regulatory authorities set deadlines for all listed companies to submit their annual report and account for example while SEC sets March 31 for all companies whose accounting year-end is December 31 of the previous year to submit its audited annual financial statement. CAMA (2004) as amended stipulates that all listed companies should make their audited reports and accounts available to the users within three (3) months after the financial year-end. Furthermore, the SEC code of corporate governance in Nigeria also requires the board of directors to ensure timeliness, accuracy, and continuous disclosure of information and activities of the company (Uthman, Ajadi and Asipita (2018). However, many listed companies in Nigeria are not complying with the SEC deadline which resulted in fines amounting to N143.6 million imposed by the Nigerian Stock Exchange on listed companies across banks, manufacturing, insurance sectors, among others (Ishaku, Muhammad \& Shuaibu 2020).

Previous studies on board characteristics and audit report lag include Apadore (2012) in Malesia; Garkaz, Abdollahi and Niknam (2016) in Tehran; Azubike and Aggreh (2014) and Uthman, Ajadi \& Asipita (2018) in Nigeria. Others on audit quality and audit report lag are Ocak and Ozden (2018) Borsa İstanbul; Saidu and Aifuwa (2020) and Muhammad (2020) in Nigeria. However, studies on board characteristics, audit quality, and audit report lag determined the joint effect of board characteristics and audit quality on audit report lag for example Ahmeda and Che-Ahmada (2016) determined the join effects of board size, audit committee characteristics, and audit quality on audit report lag (ARL) of banks listed in Nigeria. Similarly, Sakka and Jarboui (2016) determined the relationship between corporate governance, external auditor's characteristics index, and timeliness in light of the 2005 Financial Security Law amendments in Tunisia.

These studies did not however assess the moderating effect of audit quality on the relationship between board characteristics and audit report lag, and according to Ishaku, Musa and Garba (2020) quality audit helps reduce information asymmetry, plays an essential role in maintaining an efficient market environment and protect the interests of all stakeholders. Kurawa and Ishaku (2020) also assert that external auditor's verification adds credibility to the company's financial statements. Hence audit quality can moderate the relationship between board characteristics and audit reports lag in consideration that quality audit because of independence, more resources and expertise have a greater incentive to complete audit work within a short period and add credibility to the audited financial report and account. It, therefore, becomes pertinent to investigate the moderating effect of audit quality on the relationship between board characteristics and audit report lag of listed non-financial companies in Nigeria. 


\section{REVIEW OF EMPIRICAL STUDIES}

\subsection{Board Characteristics and Audit Report Lag}

Several studies written on board characteristics and audit report lag include but not limited to the following studies; Apadore (2012) examined the relationship between board independence, ownership concentration, audit committee independence, expertise, meeting, size, internal audit investment, and audit report lag of companies listed on Bursa Malaysia. The samples covered 180 companies listed at Bursa Malaysia for 2009 and 2010. Descriptive statistics were used to determine the time taken by external auditors to complete an audit work of a company. The findings revealed that on average, it takes the companies 100 days to complete their audit report with a maximum and minimum of 148 days and 26 days respectively. The regression results provide empirical evidence that audit committee size, ownership concentration, organization size, and profitability are significantly associated with audit report lag. However, the relationship between audit committee independence, meetings, expertise, types of auditors, and audit report lag is not significant.

Similarly, Alkhatib and Marji (2012) conduct an empirical investigation of factors affecting the timeliness of audit reports of listed companies in Jordan. The study sample covered 137 listed companies, secondary data was used and analyzed with regression analysis. The findings revealed that for the services sector profitability ratio, type of audit firm, and company size has a negative relationship with audit report timeliness. However, leverage has a significant relationship with audit report timeliness. Comparatively, the findings for the industrial sector show that profitability ratio, type of audit firm, company size, and leverage are negatively correlated with the timeliness of audit reports.

However, Azubike \& Aggreh (2014) investigate the determinants of audit report timeliness in Nigeria. Specifically, the study examines the relationship between company size, profitability, complexity, audit firm type, and audit report timeliness. A cross-sectional research design was used and data was extracted from annual reports of listed manufacturing companies in Nigeria for 2010-2012. Data were analyzed using ordinary least squares (OLS) regression technique. The results revealed a significant relationship between board size, independence, and audit report lag. However, the findings revealed a non-significant relationship between audit firm type and audit report lag. The study also discovered that the time lag prescribed by the regulatory bodies is too long thus encouraging companies to engage in the act of delaying their financial reports.

Similarly, Hassan (2016) employs agency theory to identify the determinants of the audit delay among listed companies on the Palestine Stock Exchange (PSE). Data were extracted from the annual reports of all the 46 listed companies on PSE for the year 2011. Multiple regression analysis was employed, and the findings revealed that board size, corporate size, the status of an audit firm, company complexity, the existence of audit committee, and ownership dispersion significantly influence audit reporting delay of listed companies on the Palestine Stock Exchange (PSE).

Garkaz, Abdollahi and Niknam (2016) determined the effect of board characteristics on the financial reporting timeliness of listed companies on the Tehran Stock Exchange. The sample size includes 107 companies from 2010 to 2014. The independent variables include board independence and board size, timeliness of financial reporting is the dependent variable. The results revealed that board independence and board size have a positive and significant relationship with the timeliness of financial reporting of listed companies on the Tehran Stock Exchange.

At the same time, Basuony, Mohamed, Hussain and Marie (2016) examined the relationship between board characteristics, ownership structure, and financial reporting timeliness, the sample size comprises of 201 companies for the period 2009 to 2013, and Ordinary Least Square (OLS) and Ridge regression analysis were used to test the audit report timeliness determinants. The findings revealed that the higher percentage of companies releasing their audited annual report in less than 60 days are audited by big four firms, this shows that big four firms are characterized by a higher audit quality. The regression results further revealed that CEO duality, board size, board independence, ownership concentration, institutional ownership, foreign ownership, auditor type, return on assets, and firm age significantly affect audit report lag.

Uthman, Ajadi and Asipita (2018) determined the relationship between board characteristics and timeliness of financial reporting of insurance companies listed in Nigeria for the period 2011-2016. The correlational research design was used, data were extracted from the annual report of the 28 listed insurance companies in Nigeria. GLS multiple regression techniques were used in analyzing the data. The findings revealed that board size has a positive and significant effect on the timeliness of financial reporting, board meeting has a significant effect on the timeliness of financial reporting of listed insurance companies in Nigeria.

Similarly, Nawafly and Alarussi (2019) conducted a study and identified the factors affecting disclosure quality of financial reporting of 150 non-financial companies listed on Bursa Malaysia, data were extracted from the annual report of the companies for the year 2014 and analyzed with regression analysis. The findings revealed that board characteristics, audit committee characteristics, and big four audit firms have a positive and significant impact on disclosure quality of financial reporting of non-financial companies listed on Bursa Malaysia. At the same time, Khudhaira, Al-Zubaidia and Rajia (2019) examined the impact of board size, audit 
committee independence, audit committee expertise, and audit committee meetings on the quality of audit of selected nonfinancial firms in Iraq. Data was collected from the annual report and account of the nonfinancial firms, the data were analyzed using the logit regression technique. The findings revealed a positive relationship between audit quality and the percentage of non-executive directors in the audit committee of non-financial firms in Iraq.

\subsection{Audit Quality and Audit Report Lag}

Studies on audit quality and audit report lag include Ocak and Ozden (2018) determined the effect of signing auditor-specific characteristics on audit report lag using 968 firm-year observations from Borsa İstanbul covering 2008-2013. The findings revealed that the gender and education level of signing auditors have a positive effect on audit report lag. Also, big-four audit firms in Turkey encourage auditees to present timely financial statements and they play a substantial role in the reporting. Audit opinion directly affects audit report lag. Firm performance and firm age inversely affect audit report lag. Moreover, big four's female signing auditors lead to more audit delay. The higher educational level of signing auditors leads to more audit report lag. Signing auditors who hold masters or Ph.D. degrees and also female signing auditors are associated with more audit report lag in firms audited by big-four and non-big-four firms.

Habib, Bhuiyan, Huang \& Miah (2018) provides a meta - analysis of the determinants of audit report lag, defined as the period between a company's fiscal year-end and the audit report date. The study group the meta - analyzed studies into three categories: (a) audit and audit-related determinants, (b) corporate governance - related determinants, and (c) firm - specific determinants. The findings revealed that audit opinion and audit season increase audit report lag, however, Big four affiliation, non-audit services, and auditor tenure decrease audit report lag. Likewise, the corporate governance determinants, the existence of a financial expert member on an audit committee, and ownership concentration reduce audit report lag. However, an examination of firm - level characteristics revealed that firm complexity increases audit report lag, whereas profitability reduces it.

Similarly, Samosir (2019) conceptually explores the influence of company internal characteristics in presenting a timely audited report which is one of the parameters for quantifying a quality audited report and found that longer audit tenure reduces auditor independence and influences the quality of audited reports negatively. However, considering audit report timeliness, longer audit tenure reduces audit report lag significantly, the study suggests the empirical investigation into the argument of elongated audit tenure on quality audit reports in terms of impaired quality and timeliness.

At the same time, Abdillah, Mardijuwono, \& Habiburrochman (2019) investigated and analyze the factors affecting auditor's efficiency in completing the audit process proxied by audit report lag of all manufacturing companies listed in the Indonesian Stock Exchange in 2014-2016. Company characteristics were proxied by the audit committee's effectiveness, financial condition, accounting complexity, and profitability, whereas auditor characteristics were proxied with auditor reputation, audit tenure, and auditors' industry specialization. Using the purposive sampling method 77 companies were selected out of the listed 231 companies, multiple linear regression analysis was used for data analysis. The findings revealed that audit committee effectiveness and profitability have a significant negative effect on audit report lag while financial conditions have a positive and significant effect on audit report lag. However, accounting complexity, auditor reputation, audit tenure, and auditors' industry specialization do not have a significant influence on audit report lag.

In the same vein, Muhammad (2020) examined the effect of auditor attributes on audit report lag of listed service companies in Nigeria. The study employed a sample of sixteen (16) listed service companies, data were extracted from annual reports of the companies understudy for 2007 to 2016, and the data were analyzed using regression analysis. The findings revealed that longer auditor tenure significantly reduces audit report lag of service companies in Nigeria. These findings imply that auditors' expertise improves in the service industry as their tenure increases which in turn accelerates and enhances the quality of audit work.

\subsection{Board Characteristics, Audit Quality and Audit Report Lag}

Studies on board characteristics, audit quality and audit report lag include Ahmeda and Che-Ahmada (2016) determine the effects of board size, audit committee characteristics, and audit quality on audit report lag (ARL) of banks listed in Nigeria. The study covered the period 2008 to 2012, data were extracted from the annual report of 14 banks. The robust OLS regression results revealed that audit quality represented by the big four audit firms has a significant impact on ARL. Board size, board meetings, total assets, and board gender also have significant positive associations with ARL. However, the findings further revealed a non-significant relationship between audit committee size, risk management committee size, and board expertise on ARL of banks listed in Nigeria.

Similarly, Sakka and Jarboui (2016) determined the relationship between corporate governance, external auditor's characteristics index, and timeliness in light of the 2005 Financial Security Law amendments in Tunisia. 
The study uses panel data methodology and covered 28 companies listed on the Tunisian Stock Exchange for the period 2006-2013. The empirical findings revealed that corporate governance improves the quality of financial reporting timeliness. The findings further revealed that whenever the audit report publication date is short, the external auditor's characteristics index is discovered to be high.

However, Saidu and Aifuwa (2020) investigated the impact of board characteristics on the audit quality of listed manufacturing firms in Nigeria. A multi-method quantitative research design was adopted, data were extracted from the annual report and account of the companies. The study employed Binary Probit Regression analysis in testing the hypotheses. The findings revealed that board size had a positive and significant impact on audit quality. The findings further revealed no evidence on the relationship between board independence, female gender on audit quality. The study also found no evidence on the moderating effect of the presence of a female on the board on the relationship between board independence and audit quality.

None of the studies reviewed determine the moderating effect of audit quality on the relationship between board characteristics and audit report lag hence and addition to the stock of knowledge.

\subsection{Theoretical Framework}

Stakeholder theory is interested in a wider set of constituents, it suggests that a company's real success lies in satisfying all its stakeholders, not just those who might profit from its stock because shareholders are merely one of many stakeholders of a company. The stakeholder ecosystem involves anyone invested and involved in, or affected by the company: employees, environmentalists near the company's plant, vendors and government agencies. As such the need for timely release of financial report and accounts cannot be underestimated, because organizational failure will be detrimental to all stakeholders. However, an effective and independent board combined with quality audit is expected to ensure total compliance with regulatory requirements to avoid regulatory fines. This theory is therefore adopted to underpin the present study.

\section{RESEARCH METHODOLOGY}

The ex-post facto research design was adopted, secondary data were extracted from the annual reports and accounts of listed non-financial companies in Nigeria for a period of six years 2013 - 2018. The population of the study comprises all non-financial companies listed on the Nigerian stock exchange as of December 2019. However, thirty-one companies were selected based on a criterion that a company must be listed and disclosed all the data needed for the study in the annual report and accounts, selected companies are contained in appendix one. In order to address endogeneity problem data were analyzed using system dynamic panel-data estimation technique.

Table 3.1 Variables of the Study and their Measurements

\begin{tabular}{|c|c|c|}
\hline Variables & Type & Measurements \\
\hline Audit Report Lag (ARL) & $\begin{array}{l}\text { Length of time between the fiscal year end of } \\
\text { a company and the date of auditors' report. }\end{array}$ & Dependent Variable \\
\hline Board size & Independent & $\begin{array}{l}\text { Total number of members sitting } \\
\text { on the board. }\end{array}$ \\
\hline Board independence & Independent & $\begin{array}{l}\text { Ratio of non-executive directors to } \\
\text { the total number of directors. }\end{array}$ \\
\hline Board meetings & Independent & $\begin{array}{l}\text { Number of meetings held by the } \\
\text { board of directors. }\end{array}$ \\
\hline Audit firm independence & Moderator & $\begin{array}{l}\text { Non audit fees divided by total } \\
\text { audit fees. }\end{array}$ \\
\hline Firm size (Fzise) & Control & Log of total assets. \\
\hline Firm age (Fage) & Control & $\begin{array}{l}\text { Number of years from date of } \\
\text { listing on NSE. }\end{array}$ \\
\hline
\end{tabular}

Source: Generated from the literature reviewed

RESULTS AND DISCUSSION

This section presents the results of the analysis conducted on the data collected from the annual report and report and account of the companies under study. The descriptive statistics, correlation, and System dynamic panel-data estimation results are presented below. 
Table 4.1 Descriptive statistics of the variables



Source: STATA OUTPUT

The descriptive statistics on Table 4.1 revealed that audit report lag has a mean of 95.957 , a standard deviation of 40.070, with a minimum and maximum of 41 and 313 respectively, the standard deviation of 40.070 signifies no variation in audit report lag of the companies within the period under study. Board size has a mean of 9.495 , a standard deviation of 2.823 , with a minimum and maximum of 5 and 17 respectively. This shows that the board size of the companies under study did not deviate significantly. Board independence has a mean of 0.724 , this means that $72.4 \%$ of the directors sitting on the board of the companies under study are non-executive directors, a standard deviation of 0.117 with a minimum and maximum of 0.462 and 0.929 respectively. Board meetings have a mean of 4.117 meaning on average the board meets four times a year with a minimum and maximum of 3 and 6 respectively and a standard deviation of 0.732 which shows that the meetings of the companies under study did not deviate significantly. Audit firm independence has a mean of 0.006 , a standard deviation of 0.031 with a minimum and maximum of 0 and 0.257 respectively.

On average the companies under study have an average size of 10.258, a standard deviation of 0.893 with the minimum and maximum of 8.419 and 12.032 respectively. The firm age has a mean of 32.11 , a minimum and maximum of 11 and 61 respectively and a standard deviation of 10.023 signifies no variation within the period under study.

\subsection{Correlation Matrix}

\section{VARIABLES AURL BSIZE BIND BMEET AUFIND FSIZE FAGE}

$\begin{array}{ccccccccc}\text { AURL | } & 1.0000 & & & & & & \\ \text { BSIZE | } & -0.0433 & 1.0000 & & & & & \\ \text { BIND | } & 0.0002 & 0.0163 & 1.0000 & & & \\ \text { BMEET | } & -0.0434 & 0.0018 & 0.1013 & 1.0000 & & \\ \text { AUFIND | } & 0.0047 & 0.2535 & 0.0372 & 0.2629 & 1.0000 & & \\ \text { FSIZE | } & 0.1183 & 0.4095 & 0.0389 & 0.0670 & -0.0049 & 1.0000 & \\ \text { FAGE | } & -0.1617 & 0.0439 & -0.0780 & 0.2264 & -0.1467 & 0.1756 & 1.0000\end{array}$

Source: STATA output

It can be seen from Table 4.2 that board size, board meetings, and firm age have a negative correlation with audit report lag other explanatory variables board independence, audit firm independence, and firm size are positively correlated with audit report lag (AURL). 
Table 4.3: System Dynamic Panel-data Estimation Results

Main Model without Moderating

Main Model with Moderating

\begin{tabular}{lcccccc} 
Variable & \multicolumn{2}{c}{ Expected sign } & Coefficient & Sig. & Coefficient & Sig. \\
AURL t-1 & & 0.3463 & 0.000 & 0.3863 & 0.000 & \\
BSIZE & $(-)$ & -1.8363 & 0.000 & -1.0936 & 0.038 \\
BIND & $(-)$ & 4.3202 & 0.680 & -10.386 & 0.399 \\
BMEETIN & (-) & 3.0816 & 0.042 & 2.8192 & 0.047
\end{tabular}

\begin{tabular}{lccc}
\hline BSIZE*AUFIND & -32.69848 & $0.000 * * *$ & Moderating \\
BIND*AUFIND & -1814.044 & $0.000^{* * *}$ & Moderating \\
BMEET*AUFIND $^{*}$ & 316.5903 & $0.000 * * *$ & Moderating
\end{tabular}

$\begin{array}{lccccc}\text { FSIZE } & (-) & -2.7048 & 0.000 & 0.5215 & 0.512 \\ \text { FAGE } & (-) & -0.8692 & 0.000 & -0.9302 & 0.000 \\ \text { CONS } & & 116.8429 & 0.000 & 97.5062 & 0.000\end{array}$

\begin{tabular}{|c|c|c|}
\hline Number of observations & 155 & 155 \\
\hline Number of Companies & 31 & 31 \\
\hline Chi $\quad 338.78$ & & \\
\hline SarganTest & & 11.421 \\
\hline Arrelano-Bond AR(2) Test & & -1.6045 \\
\hline
\end{tabular}

From table 4.3, Board characteristics, audit quality, audit report lag, and other control variables (firm size and firm age) were introduced to the model. This model, however, was found to be significant $(\mathrm{P}$-value $=0.000)$. The results in step 1 show that board size (BSIZE) has a negative and significant effect on audit report lag. Board independence (BIND) measured as the ratio of non-executive directors to the total number of directors revealed a positive but non-significant effect on audit report lag.

Board meetings measured as the number of meetings held showed a positive relationship with audit report lag implying that more meetings increase audit report lag and this relationship is significant, meaning an increase in board meetings by $1 \%$ increase audit report lag by $3.018 \%$. However, the result reveals that firm size (FSIZE) and firm age (FAGE) have a negative and significant effect on audit report lag. This is because larger and older firms have reputations coupled with effective monitoring by regulators, trade unions, and investors.

In the model, the interaction terms between audit quality and board characteristics shows the coefficient of the lagged audit report lag $\left(A U R L_{t-1}\right)$ is positive and statistically significant effect on current audit report lag suggesting that previous audit report lag has a significant effect in determining the current audit report lag $\left(A U R L_{t}\right)$ the moderating effect of audit quality in the relationship between board size and audit report lag is negative and significant. This means that audit quality has strengthened the influence of board size on audit report lag, this is because a larger board has more knowledge, experience, and expertise regarding their firms combining this with a quality audit will significantly decrease audit report lag of listed non-financial companies in Nigeria.

The interaction effect of board independence and audit quality revealed a negative and statistically significant effect on the current audit report lag, meaning audit quality has strengthened the relationship between board independence and audit report lag of listed non-financial companies in Nigeria. This finding is consistent with the findings of Hassan (2016) whose findings revealed that board size, corporate size, the status of an audit firm, company complexity, the existence of audit committee, and ownership dispersion significantly influence audit reporting delay of listed companies on Palestine Stock Exchange (PSE). Garkaz, Abdollahi and Niknam (2016) result also revealed a significant relationship between board independence, the board size, and the timeliness of financial reporting of listed companies on the Tehran Stock Exchange. Also, in line with the findings of Uthman, Ajadi, and Asipita (2018) whose random effect results revealed that board size has a positive and significant effect on the timeliness of financial reporting, board meeting has a significant effect on the timeliness of financial reporting of listed insurance companies in Nigeria. However, the findings is contrary to the findings of Ahmeda and Che-Ahmada (2016) whose robust OLS regression results revealed that board size, board meetings, total assets, and board gender have significant positive associations with ARL. The combined effect of board meetings and audit report lag showed a positive and significant relationship with audit report lag implying that more board meetings increase audit report lag even when there is audit quality and this relationship is significant. 


\section{CONCLUSION AND RECOMMENDATIONS}

This study examined the moderating effect of audit quality on the relationship between board characteristics and audit report lag of listed non-financial companies in Nigeria. Based on the findings the study concludes that board size and board meetings have a significant influence on audit report lag of listed non-financial companies in Nigeria, hence the need for an effective and independent board cannot be overemphasized. Audit quality moderates the relationship between board characteristics and audit report lag of listed non-financial companies in Nigeria and recommended strict adherence to regulatory guidelines to avoid regulatory fines.

Nevertheless, the present study concentrates only on the board characteristics (board size, board independence and board meetings), audit quality (audit firm independence measured as non-audit fees divided by total audit fees) and consider listed non-financial companies in Nigeria, hence an avenue for future studies to consider board gender diversity, board expertise in a similar or other sector of the Nigerian economy.

\section{References}

Abdillah, M. R., Mardijuwono, A. W. \& Habiburrochman, H. (2019). The effect of company characteristics and auditor characteristics to audit report lag Asian Journal of Accounting Research 4(1) ISSN: 2443-4175

Ahmeda, M. I. \& Che-Ahmada, A. (2016). Effects of Board Size, Board Committees Characteristics and Audit Quality on Audit Report Lags International Soft Science Conference

Alkhatib, K. and Marji, Q. (2012). Audit Reports Timeliness: Empirical Evidence from Jordan Procedia - Social and Behavioral Sciences 62(24) pp. 1342-1349

Apadore, K. D. (2012). Determinants of Audit Report Lag and Corporate Governance in Malaysia Thesis Submitted to Othman Yeop Abdullah Graduate School of Business, Universiti Utara Malaysia, in Fulfillment of the Requirement for the Master of Science (International Accounting)

Azubike, J.U. B. \& Aggreh, M. (2014). Corporate governance and audit delay in Nigerian quoted Companies European Journal of Accounting Auditing and Finance Research 2(10) pp.22 www.eajournals.org

Basuony, M. A. K., Mohamed, E. K.A., Hussain, M. M. and Marie, O. K. (2016) Board characteristics, ownership structure and audit report lag in the Middle East," International Journal of Corporate Governance, Inderscience Enterprises Ltd, 7(2), pp. 180-205.

Companies and Allied Matters Act (2004), CAP C20 LFN.

Garkaz, M., Abdollahi, A. and Niknam, S. (2016). Studying the effect of the board characteristics on the timeliness financial reporting of listed companies in Tehran Stock Exchange JFAMM 4(1)

Habib, A., Bhuiyan, M. B., Huang, H. J. \& Miah, M. S. (2018). Determinants of audit report lag: A meta - analysis International Journal of Auditing, 23(1) pp. 20-44, 2019

Hassan, Y. M. (2016). Determinants of audit report lag: evidence from Palestine Journal of Accounting in Emerging Economies 6(1) pp. 13-32

Ishaku, A., Musa, F. \& Garba, M. (2020). Audit Quality and Firm Value of Listed Insurance Companies in Nigeria Global scientific journal 8(7) www.globalscientificjournal.com

Ishaku, A., Aliyu, M. \& Shuaibu, K. (2020). Audit Committee Effectiveness and Audit Report Lag of Listed Non-financial Companies in Nigeria. Nigerian Journal of Accounting and Finance 12(1).

Khudhair, D., Al-Zubaidi, F \& Raji, A. (2019). The effect of board characteristics and audit committee characteristics on audit quality. Management Science Letters, 9(2) pp. 271-282

Kurawa, M. J. \& Ishaku, A. (2020). Audit Quality and Earnings Management of Listed non-financial Companies in Nigeria Global scientific journal 8(5) www.globalscientificjournal.com

Muhammad, M. I. (2020). Effects of Auditor Attributes On Audit Reporting Lag: Empirical Evidence from Nigerian Service Firms Asian Journal of Empirical Research 10(4) 127-136

Nawafly and Alarussi (2019). Impact of Board Characteristics, Audit Committee Characteristics and External Auditor on Disclosure Quality of Financial Reporting Journal of Management and Economic Studies 1(1): 48-65 https://www.jomaes.org

Ocak, M. and Ozden, E. A. (2018). Signing Auditor-Specific Characteristics and Audit Report Lag: A Research From Turkey the Journal of Applied Business Research 34(2)

SEC Code of Corporate Governance in Nigeria (2011).

Saidu, S. and Aifuwa, H. O. (2020) Board Characteristics and Audit Quality: The Moderating Role of Gender Diversity International Journal of Business Research 8(1)

Samosir, H. E. S. (2019). Audit quality report: a conceptual review of perceived effects of selected factors Academy of Accounting and Financial Studies Journal 23(3) pp. 389

Sakka, I. F. and Jarboui, A. (2016). Audit reports timeliness: Empirical evidence from Tunisia

Uthman, B. O., Ajadi, T. and Asipita, J. J. (2018). Effect of Board Characteristics on Timeliness of Financial Reporting Of Listed Insurance Firms in Nigeria Journal of Arts, Management and Social Sciences (OJAMSS); 3 (1), pg. $126-136$

Wiyantoro, L. S. \& Usman, F. (2018). Audit Tenure and Quality to Audit Report Lag in Banking European 
Research Studies Journal Volume XXI (3) pp. 417-428

First A. Author (M'76-SM'81-F'87) and the other authors may include biographies at the end of regular papers. Biographies are often not included in conference-related papers. This author became a Member (M) of Association XXXX in 1976, a Senior Member (SM) in 1981, and a Fellow (F) in 1987. The first paragraph may contain a place and/or date of birth (list place, then date). Next, the author's educational background is listed. The degrees should be listed with type of degree in what field, which institution, city, state, and country, and year degree was earned. The author's major field of study should be lower-cased.

Second A. Author (M'76-SM'81-F'87) and the other authors may include biographies at the end of regular papers. Biographies are often not included in conference-related papers. This author became a Member (M) of Association XXXX in 1976, a Senior Member (SM) in 1981, and a Fellow (F) in 1987. The first paragraph may contain a place and/or date of birth (list place, then date). Next, the author's educational background is listed. The degrees should be listed with type of degree in what field, which institution, city, state, and country, and year degree was earned. The author's major field of study should be lower-cased. 